\title{
Die invloed van Abraham Kuyper op ds. S.J. du Toit
}

\author{
Eddie Brown \\ Departement Ekklesiologie \\ Universiteit van Stellenbosch \\ Stellenbosch
}

\begin{abstract}
The well-known Rev. S.J. du loit must be understood as a prophet. Taking afier die influential minister of Paarl, the reform-minded Rev. G.W.A. van der Lingen, Rev. S.J. du Toit associated himself with the Dutch theologian and politician Abraham Kuyper, who formulated and advocated a Calvinist worldvew. Du Toit was guided by Kuyper in almost every way, but especially in his call for a free and (hristian system of education. Adopting the educational principles argued by Kuyper, he drafted a similar act of education for the Transvaal and with his aid attempled to foster a society in the Calvinist sense of the word. And yet, his prophetic vision estranged him from his Dutch reacher and friend as well as from those he so badly wanted to address and influence. Evenually he was left in the cold. Nevertheless, he proved himself as a prophet of Afrikaans ... and perhaps he was politically also not without a prophetic sense.
\end{abstract}

\section{Inleiding}

Abraham Kuyper (1837-1920)' en die "Antirevolutionaire richting" (Schutte, 1986:143 e.v.) het in eie reg bekend geword in Suid-Afrika (Schutte, 1986:171 e.v.; Van Koppen, 1992). Sonder twyfel was dit by uitstek ds. S.J. du Toit (1847-1911) wat Kuyper hier aan die woord gestel het (Scholtz, 1975; Nienaber,

1 Kyk Winckel, 1919; Kolfhaus, 1925, Rullmann. 1928, Gedenkbock Dr A Kusper, 1937, Vogel. 1937, Kastecl. 1938: Grosheide. 1939:102-120. Rullmann. 1923:40, Vandenberg. 1960, Puchinger \& Scheps. 1971. Puchinger, 1987. Kusper het natuurlik 'n lewensbeskouing gehuldig wat tcologies en wysgerig beredeneer is. daarom is die procfskrifte oor hom so belangrik Vergclyk in dic verband Praamsma. 1945. Van Lecuwen, 1946; Ridderbos. 1947: Langman. 1950: Voerman. 1954, Velema. 1957: Van Rooyen, 1964: Haitjema. 1931:331 c v, Van Ruler, s J, Dreycr. 1943-1944 21-31. Engelbrecht, 1946:46, Groot, 1956: Van der Linde. 1958:8-10. Geclhoed, 1975, Douma, 1976, Aalders, 1984.212-232: Jonker. 1989:12-23: C J Snit. 1989:24-44. J H Smit, 1989:45-55, Velema, $1989: 56-73$ 
1940; SABW: I, 279-283; J.D. Du Toit, 1917). Du Toit het Kuyper op die spoor gevolg en persoonlik geken. Die vraag is in watter sin 'Kuyper die Geweldige' invloed uitgeoefen het op 'die eensame Ismael' - dit is egter 'n aspek wat kerkhistories-kontekstueel uitgemaak moet word

\section{S.J. du Toit en W.P. de Villiers - geesteskinders van ds. G.W.A. van der Lingen (1804-1869)}

Du Toit was allereers ' $n$ geesteskind van ds. G.W.A. van der Lingen (Kitshoff, 1972), wat op gereformeerde verantwoording aangedring en "de gebeurtenissen van zijnen tijd" profeties geïnterpreteer het (S.J. du Toit, 1880; Kitshoff, 1972:36 e.v., 236 e.v.) By die leraar van Drakenstein staan Christelike onderwys en die kerkskool sentraal (Oberholster, 1956; Kitshoff, 1972:116 e.v.). Dit was vir hom 'n uitgemaakte saak dat onderwys in die moedertaal moes geskied en na die eis van artikel 21 van die Dordtse Kerkorde nie die taak van die staat is nie, maar van die kerk (Anon., 1873:281). Hy het tot hierdie oortuiging gekom deur die invloed van die Réveil en Groen van Prinsterer (1801-1876) wat die ontstaan van die staatskool gewyt het aan die godsdiensverval en die Franse Rewolusie (Anon., 1873:284). Die "regten der ouders" is ontsê, en "de kinderen beschouwt als eigendom van den Staat" (Kluit, 1936:245; Langedijk, 1931; 1953).

In die staatskool aan die Kaap het Van der Lingen die hand van die liberalisme herken (Hanekom, 1951:202; Het Volkshlad, 1868-02-06). Die godsdienslose staatskool het sy begin gehad met die skeiding van kerk en staat volgens die Skoolorde van De Mist (1804), waarin gereformeerde uitgangspunte prysgegee is. Om geloofsverdeeldheid te voorkom, het die Engelse bewind in 1839 'neutrale' skole aanvaar en beskryf in die onderwyswet van 1865 (Venter, 1929: 15). Van der Lingen het die wet nie aanvaar en daarby aangepas nie - ook omdat die onderwys nie in die moedertaal kon gegee word nie (Kitshoff, 1972: 142). Hy het dit nie teen Engels as taal gehad nie, maar teen die verengelsing van die skool en die uitsluiting van godsdiens uit die leerplan (P.S. du Toit, 1946:84; Malherbe, 1925:5; Scholtz, 1964:76-77). Vir hom was dit 'n vraag hoe 'n mens "het kind van Hollandsch- of liever Kaapsch-sprekende ouders, zoodra het ter school kwam, doormiddel van het Engelsch, dat het niet verstand, [kon] onderwijzen?" (Anon., 1873:283) Dit is veral die plattelandse kind vir wie Engels vreemd is, wat veronreg word. Volgens hom het die skole vir die kerk ernstige gevolge ingehou (Elpis, 1860:IV 60-61).

As Van der Lingen leermeester vir Du Toit was, was hy dit ook vir ds. W.P. de Villiers (1843-1908) (De Kock, 1981). Laasgenoemde begin sy bediening in 1868, 'n paar jaar voor Van der Lingen se dood, en sou hande vat met Du Toit toe hy in 1874 beroep is na Noorder-Paarl om die benadering van Van der Lingen voort te sit (De Kock, 1981:31, 40 e.v.). 
By die eerste sinode waaraan De Villiers in 1870 deelneem, het hy die kem van die probleem wat die liberaalgesindes vir die kerk geskep het, teruggevoer na Ordonnansie 7 van 1843 (De Kock, 1981:115), want hierdie ordonansie het die kerk sy reg ontneem om vry te wees. Met hierdie "administratief-despotische wetsontwerp" (Ring van Kaapstad, Notule, 1843-1846:154. Kyk verder Hanekom, 1956:4-6) kon Van der Lingen hom nooit versoen nie (Kitshoff, 1972:221 e.v.). Hy het hierdie wetsontwerp in verband gebring met Het Algemene Reglement van Nederland (Van Loon, 1942:187, 222, Volger, 1946:50). Die gevolge van die ordonnansie het Van der Lingen as profeet bewys (vgl. Hanekom, 1951: 376-386; Acta Synodi, 1852:53,865; Van der Watt, 1973:95 e.v., 139 e.v.; Cachet, 1875:177, McCarter, 1875:65; Handelinge van die Sinode van die NGK in Suid-Afrika, 1870:114).

Van der Lingen het hoë agting afgedwing, maar kon die meerderheid in die NGK nie oortuig nie. Die vraag het dus ontstaan of S.J. du Toit op wie sy mantel geval het dit sou regkry.

Oor aannames in verband met die onderwys was daar net nie eenstemmigheid nie. Ds. G. van de Wall (1828-1896, vgl. SABW: I, 858-859) het nie sy voorganger, ds. Van der Lingen, se beskouinge oor die onderwys gedeel nie (Het Volksblad, 1870-11-24, p. 10,15; vgl. verder Kitshoff, 1972:284 e.v.). Toe hy met Engelse dienste begin het, het verdeeldheid ontstaan en 'n gemeente sonder grense, Noorder-Paarl, is in 1875 gestig (Acta Synodi, 1876:179-180). Daaraan het ds. De Villiers sy goedkeuring verleen en kant gekies vir die reg van "lidmate wat sterk oortuig was van die handhawing van regsinnige standpunte" (Acta Synodi, 1876:194-196; De Kock, 1981:200).

S.J. du Toit het die eerste leraar van Noorder-Paarl geword "om pal te kan staan bij die standpunt van ds. Van der Lingen - die alleenstaner in die kerk" (J.D du Toit, 1917:19). Volgens opdrag moes hy hom beywer vir

... vrijheid van Godsdienst in scholen, handhaving van de regten die Christus zijner duur gekochte Kerk geschonken heeft; geen gemeenschap met Babel, geene verkorting van de regten, geen vormchristendom, die verklaring der Profetiën als hoogst noodzakelijkst der bemoediging voor den waren Christen in dezen tijd van algemeene achteruitgang, waar in men de ophanden zijnde toekomst des Heeren schier uit het oog verliest - De handhaving van voorouderlijke taal, zeden en gewoonten (Noorder-Paarl kerkraad, 1876:91).

S.J. du Toit se aansluiting by Van der Lingen is ooglopend; tog het hy dit op sy eie manier gedoen. Miskien moet 'n mens dit sielkundig verklaar: Du Toit was die jongste van 13 kinders en het vir homself 'n model gestel: G.W.A. van der Lingen was een, Abraham Kuyper ' $n$ ander een. Verder was hy was 'n ambisieuse 
leier, wat hom nie laat lei het nie. Met gloed het hy standpunt gestel, debatte en polemiek gevoer, maar sy oortuigings het hom op sleeptou geneem. In dié proses het hy nie altyd die beginsels waaroor hy so sterk gevoel het en persone uitmekaar gehou nie. Hy het nie gehuiwer om agter die skerms te werk nie, en het nie verdenking voorkom nie.

Hy was gereformeerd onvergenoegd met die 'nuwighede' wat in die NGK posgevat het (Oberholster, 1956:19-224). Daarby het hy ingesien dat die Hollander (en Hugenoot) aan die Kaap Afrikaanssprekend geword het. Die vraag kan gestel word of dit saamhang met die feit dat hy prys daarop gestel het dat hy "geheel uit Frans-Hugenote bloed" is (J.D. du Toit, 1917:1)

Sy passie was die Bybel, wat hy in Afrikaans wou vertaal, en profeties uitgelê het. Dit is een rede waarom 'n Genootskap van Regte Afrikaners op 14 Augustus 1874 gestig is (Scholtz, 1975:73 e.v.; Nienaber, 1974). Met sy Bybeluitleg wou hy die kerk en lidmaat, die samelewing en sy tyd betrek. Hierdie uitgangspunt en strewe is in openbare lesings en publikasies gestel en in tydskrifte uiteengesit: hy wou mense beweeg.

\section{Du Toit en sy vriend kies Kuyper as gids}

Vir di. De Villiers en Du Toit was Abraham Kuyper (1837-1920) 'n gids. Hulle wou 'n situasie soos dié van Nederland voorkom (Van Ruler, s.j.) en 'n omvattende Christelike kultuur bevorder (Pont, 1987:506-521).

Dit was De Gereformeerde Kerkbode 2 wat in 1871 die Nederlandse NeoCalvinis in Suid-Afrika bekendgestel het (1871-07-15, p. 209 e.v.; 1871-07-29, p. 228 e.v.) deur twee van sy artikels oor die uitverkiesing oor te druk. Met hierdie leerstuk, wat in die NGK op die agtergrond verdring is, het Du Toit en De Villiers erns gemaak (Scholtz, 1975:246, 251 e.v.; De Kock, 1981:331 e.v., 379 e.v.).

Du Toit het sy besorgdheid oor die marginalisering van die uitverkiesingsleer in verwytende terme gestel. In aansluiting by Kuyper sou hy 'n reeks artikels in De Getuige $^{3}$ oor die predestinasie skrywe. Hierdie artikels is uitgegee as 'n boekie met die titel De Predestinatie volgens Bijbelleer en kerkleer. op nieuw in 't licht gesteld in 1895. "Groot," sê hy, is "de schuld der kerk van onze dagen, de schuld van alle kerkgenoodschappen; want door de verzwijging of achteruitstelling der predestinatieleer wordt God in zijne eere verkort. Maar vooral groot is de schuld 
onzer Nederd Geref Kerk. Zij versteekt daardoor het kleinnood, haar gegeven, in plaats van die te dragen" (p. 3). Op 'n pastorale wyse het ds. De Villiers met hierdie aanklag van ds. Du Toit en die latere Kruisgesindes omgegaan (De Kock, 1981:380).

Du Toit se aansluiting by Kuyper was anders: albei was ingestel op 'n gereformeerde verantwoording van die NGK. De Villiers is "kerkman, herder en leraar en teoloog" (De Kock, 1981:380); Du Toit het gevolg gegee aan " 'n Afrikaanse teologie" (Scholtz, 1975:233) waarin die dogmatiese benadering van Kuyper profeties en nasionaal ge-oriënteer is (Kitshoff, 1972:236 e.v.; Scholtz, 1975:17-18).

Van Kuyper het Du Toit geleer hoe om met mense op weg te gaan. Op I April 1872 het Kuyper begin om De Standaard as dagblad van die Anti-revolutionêre party uit te gee. Hy sou hierdie dagblad redigeer tot 1920 en daarin sy gereformeerde staatkunde verwoord en as program stel. In 1877 was Du Toit al 'n intekenaar (Ring van Kaapstad, Notule 1877:107).

Die weekblad De Heraut, "een Ned Stem voor Israels Koning, het Hoofd der Gemeente" is in 1852 opgerig deur Carl Schwartz ' $n$ vriend van I. da Costa. In 1871 het Kuyper die redaksie oorgeneem en aan die tydskriftitel die onderskrif gegee "voor vrije Kerk en vrije School in het Vrije Nederland" met behoud van die ou leuse "Israels Koning, het Hoofd der Gemeente." Na die Doleansie, met die 'vrymaking' is die naam van die dagblad verander na De Heraut van de Ger Kerken (1887-01-09) tot gedurende die Tweede Wêreldoorlog. Na sy dood is dit geredigeer deur sy seun H.H. Kuyper (1864-1945). Du Toit het ook hierdie blad ontvang terwyl De Villiers ewe eens die blad gereeld gelees het (De Kock, 1981: 335 ).

\section{Du Toit se onderwyssiening}

Du Toit se onderwyssiening kan breedweg omskryf word as soortgelyk aan dié van Kuyper. Tog het hy sy onderwyssiening gestel in terme van sy eie geskiedsbeeld. Die meerderheid leraars en lidmate in die NGK het egter nie Du Toit se begrip van die hede en verlede en die onderwys gedeel nie.

Daar was algemene verontrusting oor die onderwyswetgewing van 1865 (Brown, 1987:196 e.v.; De Wekker, 1873-06-01). Anders as Van der Lingen het ds. J.H. Neethling (1826-1904) c.s. egter daarby aangepas en gesorg vir "christelijke onderwijzers" (Elpis, 1873 no 4). A. Murray (jnr) het Christelike onderwyseresse vanaf Mount Holyoke (De Kock, 1981:136-137) ingevoer en Ladies Seminaries begin (Du Plessis, 1920:405 425). In 1873 het hy Die Hugenoteskool te Wellington begin om onderwyseresse op te lei (Du Plessis, 1920:285 e.v.). 
Murray en sy geesgenote het pragmaties oor Hollands as moedertaal gedink, omdat hulle die Engelse bewind van die eertydse Nederlandse kolonie aanvaar het. Vir hulle staan die geskiedenis van die Kaap en sy kerk in die teken van 'n akkommodasie, soos God dit beskik. Die Skotse leraar ds. John M. McCarter (1833-1908) (SABW:I, 506-507) het hierdie vertolking van die geskiedenis verwoord (McCarter, 1875:17-18). Anders as U.G. Lauts (1787-1865) (SABW: II, 488-489) se weergawe (Lauts, 1847) bring hy die "overgang tot het Engelsche Bestuur" in verband met God, wat in die "overleggingen" van Europa besig was "om zijn raad te volbrengen, of dat Hij, bij wien de wegen van alles zijn, het zou gebruiken om groote dingen te doen ontstaan ter bevordering van zijn koninkrijk in Afrika" (McCarter, 1875:39).

Anders as die Skot McCarter, het die Nederlander Frans Lion-Cachet (18351899) (SABW: I, 148-151), soos Lauts, die geskiedenis gaan beredeneer en die Boere, nie die Engelse nie, aangewys as baanbrekers van die Christelike geloof en beskawing in Afrika (McCarter, 1875:34).

Die gerefonneerde siening van die onderwys het S.J. du Toit verbind aan 'n geskiedsbeeld, waarin die Afrikaanse nasionalisme homself aankondig. Hierdie siening is aangeteken in drie werkies van 1876 waarin hy aangedui het wat hy wou doen, waarom hy dit wou doen en hoe hy dit wou doen. Hiervolgens staan die Christelike skool voorop en die Kerkorde van Dordt kry sodoende historiese beduidenis. Daarvolgens neem die kerkraad verantwoordelikheid vir skole om die kinders "inder Godsaligheyt ende inden Catehismo" te onderrig. Die sogenaamde neutrale onderwys sonder die Bybel is 'n dwaling van "de ongoddelijke, Revolutie" (Du Toit, 1878; kyk ook die herdruk in Coetzee, 1946:56-57). Du Toit verwyt die NGK dat hy daaraan meedoen met sy 'aanvaarding' van staatskole in terme van die Onderwyswet van 1865 (Coetzee, 1946:63). Volgens $\mathrm{Du}$ Toit is hierdie skole alles behalwe nie-sektaries; hulle is nie-Christelik (Coetzee, 1946: 69-75), soos talle Europese en Suid-Afrikaanse skrywers reeds uitgewys het (Coetzee, 1946:106-124). Teen hierdie agtergronde kry Kuyper dan betekenis: al die onderwys moet in 'n Christelike gees gegee word, die hele skool moet die eiendom van Christus wees en die kind moet daarvan bewus wees. Daarom staan hy die V'rywillige heginsel in die ondenwys voor (Venter, 1929:84, Badenhorst, 1955:134-142; Kerkbode, 1954-08-14; Hanekom, 1951:316).

In die volgende jaar vertolk Du Toit die Christelike geskiedenis van sy vaderland. In die taal eie aan sy volk wou die 'Afrikaanse' teoloog van Hugenote-afkoms allereers histories vasstel "wat is nou waar?...En hoe sit di dinge in mekaar?" Sy werkie Di geskidenis van ons land, in di taal van ons volk van 1877 noem Van Jaarsveld "'n geskiedenisontdekking" (Van Jaarsveld, 1959:93). 
Een ding is waar, die bewoners van die land, wat ontwikkel het uit die Hollanders en Hugenote as ' $n$ volk met ' $n$ gemeenskaplike taal (Du Toit, 1895:48), is deur die Britse goewerneurs veronreg (Du Toit, 1895:51 e.v.). Anders as Cachet, word die Hugenote voorgehou as 'n korrektief in die wording van 'n volk in die Hollandse kolonie. Hulle "is hiir gestuur as di sout om di jonge Koloni ver allerhande verderf te bewaar". Vir Du Toit, het uit dié proses 'n Afrikaanse volk na vore gekom, 'n volk met 'n Hugenotetradisie en -bewussyn (Du Toit, 1895:49). In Die Afrikaanse Almanak van 1877 het hy aan die hand gedoen dat 'n skool as gedenkteken aan die Hugenote opgerig word om Christelik-nasionale onderwys te bevorder.

Sy betoog, veral oor die onderwys, het 'n debat aan die gang gesit (Elpis, Okt. 1876:234-285, Jan. 1877:17-63; en Du Toit se brosjure van 1877). Sy aanvegbare stelling dat die staat hom die reg aanmatig om die onderwys te reël omdat hy anti-Christelik is, (Du Toit, 1877:56-57) het sy standpunt en die beweging vir ' $\mathrm{n}$ "Vrije Christelike School" volgens die Vrywillige beginsel nie bevorder nie (Coetzee, 1946:36).

\section{Du Toit bedryf gereformeerde politiek}

In belang van 'n vrye Christelike skool het Du Toit, in navolging van die voorbeeld van Kuyper, gerefonneerd politiek begin bedryf. In die jaar 1877 het Di Afrikaanse Patriot ${ }^{4}$ (1876-1904) 'n weekblad geword en hom inderdaad met die politiek bemoei (kyk Scholtz, 1975:82 e.v.). In hierdie weekblad het Du Toit met sy Afrikaanse en gereforneerde wêreldbeskouing na vore gekom. Hy het profeties met sy gemeenskap op weg gegaan en die sinode sowel as leraars van die NGK skerp gekritiseer.

Met die "menigte Engelsgesinde predikante" wat van die NGK 'n "Dutch Reformed Church" wou maak, kon hy nie vir lief neem nie (D.A.P., 1877-05-11). In 'n reeks artikels vanaf 25 Julie 1877, "Een sprekend portret van de Laaste Dagen," is die kerk met 'n bedekte segswyse aangekla. Openlik het hy dit verwyt van Arminianisme, die ontkenning van die wedergeboorte as 'n-werk van die Heilige Gees en die beklemtoning van bekering en geestelike opwekkings "als het eene nodige ter zaligheid" (Du Toit, 1880:24). Met die godsdienstige boekies wat in die huise van Afrikaners gelees word, het hy geen vrede gehad nie: volgens Du Toit het hierdie boekies die Huisbybel verdring en was dit die oorsaak "van het godsdienstig en zedelijk verval van ons volk" (Du Toit, 1880:162). In die NGK het sy geskrif nie as 'n "getuigenis voor de waarheid" oorgekom nie (Du Toit, 1880:iv): sy aantygings is polemies afgewys as eie aan die beredenering 
van die Afskeiding van 1859 en as onnodige verdagmakery (vir ' $n$ voorbeeld sien Beijer, s.j.: 68-103).

Ook ds. De Villiers het nie geskroom om hom met die politiek te bemoei nie - hy bly egter herder en leraar. Hy werk met Du Toit saam aan 'n "Bijbels Dagboek" met ' $n$ profetiese uitleg en bestry ook die "nuwighede" in die kerk (De Kock, 1981:229-230,248), maar hy vervreem hom nie van die kerkverband nie.

Die geskiedenis sou Afrikaners laat identifiseer met die geskiedsbeeld wat Du Toit geskep het van die Engelse se rol aan die Kaap. Hierdie identifikasie word gevestig met hulle bewuswording met die Engelse anneksasie van Transvaal in 1877. Vrae is oor die Engelse bewind opgeroep, maar kerklike vergaderings het die Engelse ingrype verswyg. De Gereformeerde Kerkbode het ook niks daaroor gesê nie.

Di Afrikaanse Patriot (1877-06-08) het egter van hom laat hoor, saam met De Zuid-Afrikaan (1877-06-06) en De Volkstem (1877-06-20). Di Afrikaanse Patrot het optrede gevra (1877-01-05; 1877-02-02; 1877-03-09; 1877-03-16). J.H. Hofmeyr (Onse Jan) (1845-1909) het predikante versoek om gemeentelede aan te moedig om 'n petisie teen anneksasie te teken (De Zuid-Afrikaan, 1877-05-05)

Di. De Villiers, Cachet en Du Toit het sonder meer die Engelse daad afgekeur (De Zuid-Afrikaan, 1877-05-16; 1877-06-06; D.A.P., 1877-06-08). Die profesieë, so was De Villiers oortuig, is besig om in vervulling te gaan. Volgens Matteus 24:12 sal in die laaste dae die ongeregtigheid vermeerder en die liefde van die meeste verkoel (De Zuid-Afrikaan, 1877-06-06; D.A.P., 1877-06-08). Die feit dat De Villiers 'n chilias was, het moontlik bygedra tot hierdie siening (De Kock, 1981:182 e.v.).

Gedurende hierdie tyd was die Afrikaner in die Noorde bedreig, in die Suide was hy sonder verteenwoordiging; gevolglik is na leiers gesoek. In 1878 is die Boeren Beschermings Vereeniging deur Onse Jan (Hofineyr) gestig - ' $\mathrm{n}$ vereniging waaruit die Afrikanerbond sou ontwikkel (De Zuid-Afrikaan, 1878-08-14; Hofmeyr \& Reitz, 1913:165 e.v.; Davenport, 1966:12 e.v.). Op Camavon het ds. De Villiers ook ' $n$ tak van hierdie vereniging gestig.

In 1879 het ds. De Villiers hom laat nomineer as kandidaat vir die Wetgewende Vergadering in die kiesafdeling Beaufort-Wes, alleen maar "ten einde de belangen van het Christelijk onderwys voor te staan" (De Zuid-Afrikaan, 1879-04-01; Smit, 1945:48; Vivier, 1975:12). Ook ds. S.J. du Toit en dr. J.J. Kotze van Richmond is gevra om hulle te laat nomineer. Du Toit het die goedkeuring van die kerkraad gehad (De Zuid-Afrikaan, 1879-01-25, D.A.P., 1879-02-28). Die versoek aan albei het nie geslaag nie en in hulle plek is D.F. du Toit (Oom Loko- 
motief) (1846-1923) (SABW:II, 212-214), ' $n$ ander leier in die GRA, benoem (Scholtz, 1975:62 e.v.; D.A.P., 1879-02-28).

Sonder om vergadering te hou, is die eertydse leraar van Beaufort-Wes verkies tot die Wetgewende Vergadering en Oom Lokomotief het uitgeval. In De Heraut het Abraham Kuyper die uitslag as "een nieuwe phase in ons kerkelijk-politiek leven" aangekondig, naamlik "dat ds. W. de Villiers, predikant van Carnavon, lid van het parlement geworden is ... Het doel zijner verkiezing is om het parlement te bewerken dat de scholen niet onder het bestuur der districtraden komen" ( $D e$ Heraut, 1879-06-22).

De Villiers het 'n tweeledige taak onderneem: hy wou die kerk oortuig dat gereformeerd gesproke, vrye skole in 'n plurale samelewing die antwoord is, en hy wou die Wetgewende Vergadering oorreed om Christelike skole finansieel te ondersteun ( The Cape Argus, 1879-07-29; The Standard and Mail, 1879-07-31; kyk ook Venter, 1929:41) ondat "any measure which tended to separate religion from education [is] ... disastrous to the cause of morality" (The Cape Argus, 1879-07-29). Vir die Prokureur-generaal het hierdie skole neergekom op kerkbeheerde inrigtings waarin wetenskaplike ondersoek nie teregkom nie terwyl historiese insigte skade ly (The (ape Argus, 1879-07-29).

D.A.P. (1879-08-01) het daarop gewys "dat geen een selfs 'n poging gewaag het om sijn onomstotelijke argumente te weerleg nie". The Cape Argus het De Villiers afgemaak as 'n rariteit van "de oue tijd". Volgens The Standard and Mail was hy "zijn tijd" 20 of 30 jaar vooruit! Die meeste lidınate en leraars sowel as die sinode van die NGK het hom nie ondersteun nie (De Kock, 1981:227). Wet 13 van 1865 het voorsiening gemaak dat godsdiensonderrig aangebied word "in addition to the ordinary school hours" (Cilliers, 1953:77-79), en daar moes slegs gesorg word dat onderwysers uitgesproke Christene is. Vir prof. Hofmeyr was dit ' $n$ beter reëling, want kerkskole is nie vry van sektariese en kerkistiese neigings nie en hulle kan verbittering en uiteindelike vyandskap teenoor die kerk en godsdiens kweek. Staatsondersteuning van vrye skole sou slegs die Rooms-Katolieke Kerk, wat reeds soveel Protestantse kinders in hulle skole het, baat (De Zuid-Afrikaan, 1879-08-30).

\section{Die gereformeerdgesinde Kuyper bly Du Toit beïnvloed}

Wat Kuyper gedoen het, het vir Du Toit belangrik gebly. In 1879 het hy 'n program van beginsels vir sy politieke party opgestel (Ons Program) waarin hy sy gereformeerde uitgangspunte gestel het. In 1879 het Du Toit begin pleit vir die oprigting van 'n politicke party, "waarin al wat Afrikaner is sig kan thuis voel en samewerk tot heil van 'n Verenigde Suid-Afrika ... waarin almal wat Afrika erken 
as hulle Vaderland" (D.A.P.,1879-06-20). Die eerste tak van die Afrikanerbond is in 1879 op Hopetown gestig.

Die volgende jaar het hy die buiteland besoek en kennisgemaak met "dr. A. Kuyper en Groen van Prinsterer, gereformeerde leiers van die sogenaamde AntiRevolusionêre Party in Nederland, manne wat die liberalisme op godsdienstige gebied bestry het en hul vir Christelike-nasionale onderwys beywer het" (Van der Walt, 1944:15). Hy het twee maal met Kuyper gesprek gaan voer (Scholtz, 1975:56; S.J. du Toit - Kerkraad van Noorder-Paarl, [1880-08-11] in Briewe Noorder-Paarl, 1876; S.J. du Toit, 1881:222-231) en vir 'n paar jaar het hulle gekorrespondeer (Scholtz, 1975:56).

In 1880 het Kuyper sy onderwysbeleid verder gevoer en die Vrije Universiteit van Amsterdam gestig (Rullmann, 1930; Gedenkboek. 1931; Roelink, 1956; Stellingwerff, 1987). Du Toit sou die eerste wees om 'n student te oorreed om hom aan die inrigting te laat oplei - hy was die gebore Paarliet S.J. van der Spuy. In 1886 het hy die eerste leraar van die NHGK in Zeerust geword (Scholtz, 1975:180; Maeder, 1916:221; K.B., 1886-08-13, p. 257; 1926-02-17, p. 58).

Op 17 Desember 1880 is ' $n$ komitee gevorm om Du Toit se voorstel van 1877 te laat gestalte kry en 'n vrye Hugenote Gedenkskool op te rig (D.A.P., 1880-12-24; Afrikaanse Almanak, 1881). Du Toit noem dit "Die Regte Hugenoteskool" waarskynlik om dit te onderskei van Murray se Hugenotekollege (Coertzen, 1988:148).

Soos Kuyper het Du Toit ook 'n tydskrif beplan (Scholtz, 1975:59), wat, soos De Heraut 'n vrye kerk en 'n Christelike skool in 'n gereformeerde sin moes bevorder. Die prospektus het die redakteur van die $K . B$. nie aangestaan nie: hy vind daarin "een geest van wantrouwen en veroordeeling tegen de leeraars onzer kerk, die ons in strijd schijnt te zijn met de Schrift en de waarheid" (1879-11-22, p. 403). Du Toit het die vermoede beaam (D.A.P., 1879-11-28) en kon hom nie vereenselwig met A. Murray se bewering dat die kerk 'n oorwinning oor die liberale rigting behaal het nie. Hy kon nie prof. Hofmeyr se ingenomendheid met die openbare skool deel nie en het eksepsie geneem teen die kritiek wat hy op sy Christelike skool daarop nagehou het (Elpis, Sept. 1879:193-208).

Die Sinode van 1880 (vgl. Scholtz, 1975:96 e.v.) het hom uitgespreek teen "den geest en de strekking ... van het weekblad, genoemd De Afrikaanse Patriot" (Acta Synodi, 1880:890; Acta Synodi, 126-128). De Zuid-Afrikaan (1830-1890) het vir die blad in die bresse getree omdat dit liefde kweek "voor de taal en de geschiedenis des volks" (1880-11-06). Het Volkshlad (1856-1875) het die sinode daarop gewys dat die "blad in een taal geschreven is en denkbeelden in omloop brengt die de bevolking verstaat" (1880-10-28). Daarom, oordeel Scholtz, is die voorstel van ds. A.A. Louw van Murraysburg deur die sinode aanvaar, naamlik om die 
Parlement te versoek om Nederlands meer tot sy reg te laat kom op die skole en Nederlands as vak verpligtend te stel in die eksamens van voornemende onderwysers (Scholtz, 1975:99; Acta Synodi:126-128). D.A.P. het daarop gewys dat 37 daarteen gestem het (1880-11-26). In teenstelling tot die leraar het die ouderling van Stellenbosch dit betreur dat so min kinders Hollands op skool geleer het (Badenhorst, 1955:128).

Na die Sinode het 'n groep predikante, waaronder S.J. du Toit, petisies vir die gelykberegtiging van Nederlands met Engels op skole en in die Parlement laat teken (I).A.P., 1881-03-11).

\section{Profetiese belewing van die Eerste Vryheidsoorlog}

Op 16 Desember 1880 het die Eerste Vryheidsoorlog begin (Van der Walt, s.j.: 311-317, Muller, 1937:274-277). Die vraag of dié oorlog Christelik regverdig was, is nie amptelik gestel nie, maar baie lidmate in die NGK van die Kaapkolonie het die wil van God daarin gesien (Mouton, 1980). De Villiers (De Kock, 1981:237 e.v.) en Du Toit het deur middel van geskrifte in D.A.P. Engeland vir die oorlog verantwoordelik gehou. Andrew Murray (jnr.) vir wie De Villiers so 'n groot waardering gehad het, het nie standpunt ingeneem in De Christen, wat De Gereformeerde Kerkbode in 1880 vervang het en waarvan hy redakteur was nie. Sy optrede "moes De Villiers teleurgestel het" (De Kock, 1981:237, 239). D.A.P. het berig dat die talle vergaderings wat in verband met die oorlog in Transvaal gehou is, hom nie aangestaan het nie - aan sy kerkraad sou hy gesê het: "Die eer van die Britse vlag is geschonde; dit moet gehandhaaf worde" (D.A.P., 1881-02-04; 1881-02-12).

Die oorwinning van die ZAR is in die Paarl gevier met Du Toit en De Villiers aan die "feesdis" (ID.A.P., 1881-04-01). Du Toit het die uitslag na aanleiding van 2 Konings 10:15 profeties vertolk. In De Getuige het hy die Britse imperialisme in verband met die toring van Babel en die Antichris gebring (1881-04-01).

'n Afrikaner-nasionalisme is verder gevoer, en evangeliesgesindes_sou hulle daarvoor laat vind. Die ideaal dat "alle Hollandsch-Afrikaansche harten in geheel Zuid-Afrika tot één hart waren saamgesınolten" het prof. Hofmeyr laat sê "Ik zie hierin Gods vinger" (D. (J., 1881-08-24, Kestell, 1911:209-210).

Die oorlog het Nederlanders hulle "Afrikaner neven," wat nog steeds prys gestel het op hulle taal, laat herontdek (Schutte, 1986:9 e.v.) en daar is opnuut vanuit die verlede oor die hede gedink. 


\section{Du Toit dring aan op gereformeerde verantwoording}

Op 15 Januarie 1881 het die maandblad De Getuige (-1904) verskyn om die lesers terug te voer na "het geloof eenmaal de heiligen over geleverd (Judas vs. 3), vooral zooals op het laatst en duidelijkst en zuiverst omschreven is in onze Formulieren van Enigheid, vastgesteld te Dordt 1618 en 1619" (De Getuige, 1881-01-15, p. 2). In De Getuige het Du Toit sy gereformeerde benadering verwoord, die NGK konfessioneel beoordeel en uiteindelik kruiskerke gaan bedien.

In sy poging om die gereformeerde benadering te verwoord, is die hulp van Kuyper ingeroep en veral van sy preke is oorgeneem (D.G., 1881-07-15, p. 97 e.v.). $\mathrm{Na}$ 'n jaar het die blad ongeveer 4,000 intekenare gehad, "ongetwijfeld meer dan ... enig Hollandsch tijdschrift in Zuid-Afrika" (D.G., 1882-01-15)

In hierdie tydskrif is voortdurend gevra vir godsdiensvryheid op skool. In dié verband het 'n petisie van S.J. du Toit op 11 Mei 1881 by die Wetgewende Vergadering gedien. Hierdie petisie van S.J. du Toit en andere was deur 5,000-6,000 handtekeninge van oor die hele Kolonie gerugsteun (Coetzee, 1946:37). Die voorstel van De Villiers vir staatsondersteuning van privaatskole het egter verdere ondersteuning kortgekom (Venter, 1929:42; De Zuid-Afrikaan. 1881-05-14; D.A.P., 1881-05-13; Het Volksblad, 1881-05-14).

Na die sitting het De Villiers as lid bedank. Die Patriot het sy ywer vir die vrye skool voortgesit en die sogenaamde neutrale skool aan die kaak gestel. Die Afrikanerbond het die rede vir vrye skole ingesien (Coetzee, 1946:36); ook die Gereformeerde Kerk het hierdie skole voorgestaan (Venter, 1929:49-50; D.A.P., 1881-04-01; Du Toit, s.j.:6-7). Die professore van die Gereformeerde Teologiese Skool van Burgersdorp het in 1881 besluit om hulle te beywer vir 'n "skool met die Bybel," kerkskole sonder enige steun van owerheidsweë (Venter, 1929:50; Potgieter, 1961:244-251).

\section{As Superintendent van Onderwys in Transvaal vat Du Toit hande met Kuyper}

In 1881 het $\mathrm{Du}$ Toit die betrekking van Superintendent van Onderwys in Transvaal aanvaar (Scholtz, 1975:141 e.v.) Hy het Kuyper daarvan laat weet en met hom in verbinding gebly (Van der Walt, 1944:15) sodat hy hom kon help met ' $n$ regstelling.

In sy nuwe betrekking staan die navolging van die voorstaander van Christelike skole en grondlêer van die Vrije Universiteit aangeteken. In artikel 12 van Ons Program (Kuyper, 1879) word die ouer verantwoordelik gehou vir die onderwys van sy kind. In die onderwyswet wat Du Toit vir die ZAR ontwerp het, gaan die 
"Regering der ZA Republiek" uit van "het beginsel dat het de taak is der ouders te zorgen voor het onderwijs hunner kinderen", en beperk die staat se "bemoeijingen met het Schoolwezen" (Jeppe \& Kotze, 1887:1069-1071). Die skole sou finansieel deur die owerheid ondersteun word. Die skole moes hulle hou aan 'n "Christelike gees;" geopen en gesluit word "met gebed, en lezen van Gods Woord en die behandeling der Bijbelgeschiedenis binnen de School uren" terwyl "het bepaald confessioneel (leerstellig) onderwijs aan de respectieve Kerkbesturen wordt overgelaten". Die regering het dit wenslik geag "dat de verschillende Gemeenten en Kerkeraden zelf ... het initiatief nemen in stichten van Scholen en het kiezen van School commissien" (art 2). Du Toit is van handboeke voorsien deur die Nederlandsch-Zuid-Afrikaansche Vereniging, waarvan Kuyper voorsitter was (Scholtz, 1975:152).

Die Nederlanders wat pres. Burgers vir die ZAR gewerf het (vgl. Wypkema, 1939), het die Superintendent van Onderwys verontrus. Hy het pres. Kruger (Schutte, 1968) gehelp om met Kuyper se hulp die regte Nederlandse immigrante te vind. Die verhouding waarin die Transvaal tot Nederland gedurende die periode 1875 tot 1900 te staan sou kom, word deur G.J. Sclutte getipeer in terme van "Haat-liefde" (Sclutte, 1986:101 e.v.).

Nog voor die eerste jaar om was, kon Du Toit aan Kuyper skrywe dat hy pres. Paul Kruger se regterhand is D.J.P. Jorissen (1829-1912) (SABW: II, 353-356; Jorissen, 1897) c.s. moes terugtree (Ploeger, 1945:39 e.v., 1946:32 e.v.; Kruger, 1975). Hierdie eertydse Nederlandse predikant wat deur pres. T.F. Burgers (1834-1881) gewerf is vir sy beplande staatsgimnasium was 'n vrymesselaar (Cooper, 1986:101, 153, 178). Voor sy vertrek uit Groningen in 1875 het hy by die beweging aangesluit (SABW: 11, 355) en gepromoveer met die proefskrif "Kerk en staat." "As volgeling, onder meer van J.S. Mill en die vrysinnige Amerikaanse teoloog Theodor Parker, besluit Jorissen in Kaapstad, daartoe aangeraai deur die Transvaalse konsul, J. Marquard, om hom weens sy wysgerige en teologiese opvattinge nie met die Transvaalse onderwysaangeleenthede te bemoei nie" (SABW: II, 353). So word hy staatsprokureur. "Als Burgers-man en vrijzinnigliberaal had Jorissen weinig sympathie voor de ineer behoudende Transvaalsche elemente ... hij deed zelfs geen poging Afrikaans te spreken" (Schutte, 1968:201).

Aan Kuyper berig Du Toit: "Die modeme heeren zien mij ... met nijdige oogen aan, doch onderwerpen zich geveinsdelijk." "Ziet gij geen kans," so vra hy hom, "een degelijken rechtsgeleerde van Geref beginselen, uit Holland te leveren, tot Staatsprocureur." Hy sou sorg om "onzen modernen predikant, die nu hier rechtsgeleerde speelt, op pensioen te laten ontslagen. Ook Kruger wenscht dit met mij" (aangehaal deur Scholtz, 1975:153). Du Toit sou egter sy hand oorspeel Jorissen was nie sonder aanhang me (Schutte, 1968:201 e.v.). De Volksstem (1883-08-01) noem hom met verwysing na sy Memorie "de ziel en het brein ... 
van den Transvaalsche Vrijheidsoorlog". "Wat in deze Memorie opvalt," so wys Schutte (1968:202) daarop "is de typisch Nederlandse, volkenrechtelijke benadering van een internationaal conflict, het beroep van de zwakste partij op zijn rechtspositie; de afkeer ook van de machtspolitiek die de grote mogendheden zich tegen kleine staten menen te mogen veroorloven". Schutte (1968:203) stel sy saak met ' $n$ historiese oorsig van Britse verontregting in Suid-Afrika en haal vergelykenderwys uit die Nederlandse geskiedenis aan. Nog ander Hollanders sou met hierdie liberale argumentasie Afrikaner-nasionalisme dien, by name W.J. Leyds (Van Jaarsveld, 1954:97-107).

\section{Die bevordering van Christelike onderwys in die Kaapkolonie}

Steeds met Kuyper as gids, het $\mathrm{Du}$ Toit hom vanuit Transvaal voortdurend beywer vir die bevordering van die Christelike onderwys in die Kaapkolonie (Scholtz, 1975:109 e.v.). Die Gedenkskool der Hugenoten, waarvoor hy hom beywer het, is in Februarie 1882 geopen op die familieplaas, Kleinbosch (ID.A.P., 1882:102; kyk ook Nienaber, 1968:7 e.v.). Nederland het 'n vrye universiteit gehad, die Kaap het 'n vrye skool gekry. Onder die sprekers by die openingsgeleentheid was Andrew Murray tog nie uitgesluit nie. Opvallend is die feit dat die skool vry wou bly van finansiele ondersteuning deur die Staat. Algaande is die skool as 'anti-Engels' uitgemaak. Uiteindelik is staatsondersteuning in 1895 gevra, nadat Du Toit Britsgesind geword het. In 1910 is die inrigting gesluit.

Met die hulp van die Afrikanerbond wou hy die Christelike onderwys ook in die Kaapkolonie juridies moontlik - en 'n verenigde Suid-Afrika - 'n werklikheid maak. Hierdie laaste motief sou al sterker by hom begin funksioneer. In navolging van Kuyper het hy in 1882 ' $n$ "Program van Beginselen van de Nasionale Party, opgesteld, verklaard en toegelicht" (Paarl, 1884). Daanmee het hy die Afrikanerbond aan die hand van die Anti-Revolusionêre Party geprogrammeer (p. 1). "Ons Program," so laat hy Kuyper weet, "heb ik gewijzigd ook voor Z Afr het 'onze' gemaakt, althans: ik twijfel geenzins of het zal in hoofdzaak alhier overgenomen worden" (aangehaal deur Scholtz, 1975:135). Tereg noem Scholtz dit "die eerste uitvoerige politieke geloofsbelydenis wat deur 'n Afrikaner opgestel is", 'n politieke geloofsbelydenis deur 'n Afrikaner-Calvinis (Scholtz, 1975:135).

Ook vir Du Toit was God die bron van soewereine gesag. "Noch in den Volkswil", so lui artikel 2, "noch in de Wet, maar alleen in God vindt zij [de Bond] de bron van het souverein gezag, en venwerpt mitsdien eenerzijds het beginsel van een wettelooze volksouvereiniteit en anderzijds alle wederrechtelijke vreemde overheerzing ..." (Du Toit, 1984:10, 11).

Die meerderheid Kapenaars is egter nie deur sy beginsels beïnvloed nie (Davenport, 1966:51-53); daarom is dit 'n oorvereenvoudiging om te beweer dat Kuyper 
aan die hand van Du Toit en latere volgelinge verantwoordelik is vir die beleid van apartheid wat die Nasionale Party later sou toepas (vgl. Hexham, 1981:32, $54,59-60,83,116,189,197)$.

"Die Program" het die onderwys as taak van die ouer onder toesig van die kerk en in terme van die "Vrijwillig Beginsel op Schoolgebied" gestel (Hexham, 1981:6674). Du Toit se onderwysbeleid wat in Transvaal staatserkenning gekry het, het 'n debat in die Kaapkolonie uitgelok. De Villiers en M.P.A. Coetzee, leraar van die G.K. Burgersdorp (kyk Ras, 1979) het die vrye skool verdedig (De Villiers \& Coetzee, s.j.) teen onder andere dr. S. Hofineyr van Montagu en ds. D. Ross van Lady Grey (sien lg. se werkie: Bezwaren tegen de Toepassing van het Vrijwillig Beginselen op Scholen) wat volgehou het dat die onderwys "uitsluitlik" die plig van die staat is.

Omdat "Die Program" van Du Toit die afskeiding van Engeland onderskrywe het en anti-Engels was, was dit vir sy politieke bondgenoot, J.H. Hofmeyr (Onse Jan), nie aanvaarbaar nie. Ook "het organiseren van staat en maatschappij ... naar de beginselen van het Calvinisme" het hom blykbaar nie aangestaan nie (De ZuidAfrikaan, 1884-04-09).

\section{W.P. de Villiers se optrede}

Anders as S.J. du Toit, is W.P. de Villiers se benadering ten opsigte van Christelike onderwys positief en tree hy, in navolging van Kuyper, kerklik op. Hy het die onderwyskwessie steeds op kerklike wyse gestel. Meer en meer mense sou begin aandring op Hollands as medium van onderwys, maar vir 'n vrye kerk en skool was hulle nie te vinde nie. De Villiers deel Kuyper mee dat slegs hy en drie ander leraars, te wete S.J. du Toit, A. Steytler en G. van Niekerk "bezwaar hebben om mee te doen" aan die bestaande onderwysstelsel. Tog het die vrye skole gedurende daardie tydperk byval by mense gevind, veral omdat daar 'n oplewing van Afrikaner-nasionalisme ervaar word. Voorts sou hy aangedring op gelyke regte vir die vrye skole met die openbare skole.

In 1882 het Onse Jan reggekry om in die Wetgewende Vergadering debatte ook in Hollands te laat voer (D.A.P., 1881-12-16; De Zuid-Afrıkaan, 1882-04-01; De Express, 1882-04-17, kyk ook De Villiers, 1936:112-113). By die Sinode van 1883 het petisies aangedring op Hollandse onderrig en De Villiers het gevra om "het onderwijs in de Hollandsche taal op alle mogelijke wijze te bevorderen" (Van Niekerk, 1920:46-47). So 'n versoek is na die SGO gestuur en 'n beweging het aan die gang gekom (Acta Synodi, 1883:139; Badenhorst, 1955:133-134).

Vir Du Toit en De Villiers het die aanvaarding van staatskole in die teken van kerklike aanpassings gestaan. Hulle was verheug oor die bekommemis van gemeentes (De Kock, 1981:247 e.v.), oor wat genoem is "Nuwighede," "Nieuwe 
zangwijze; het zingen van Kinderharp en Sankey's liederen; het preken van vrouwen; het oprichting van geheime genootschappen; het leger des heils" (Acta Synodi, 1883:893 e.v.). Op grond hiervan pleit De Villiers weer vir die afskaffing van Ordonnansie 7-1843 (De Kock, 1981:256); ook die kerk moes vry wees.

Vir 'n vrye skool is nog steeds nie kans gesien nie. In 'n brief in De Zuid-Afrikaan (1885-03-28) het dr. S. Hofineyr hom weer daarteen uitgespreek omdat dit "een geweldige slag aan de zaak van het onderwijs in ons land zal toebracht". Nog briewe sou volg (1885-04-02; 1885-04-09; 1885-04-14; 1885-04-25; 1885 $05-02 ; 1885-05-07 ; 1885-06-02 ; 1885-07-02)$. Daar is gesê dat die owerheid "Volkscholen" moontlik gemaak het omdat vryheid tot "godsdiensonderwijs ... ruimschoots gegeven" word (De Zuid-Afrikaan, 1885-04-09). Ds. Coetzee het dit egter betwyfel, want in 'n volkskool is die volkstaal die medium van onderrig, die godsdiens van die volk hoofsaak en het die vaderlandse geskiedenis 'n ereplek. De Villiers wys daarop dat in die staatskool godsdiensonderrig nie deel van die gewone skoolwerk is nie en dat dit gaan om "een lewenskwestie" wat die toekoms van land en kerk raak. Hy haal Kuyper aan en wys daarop dat "op het stuk van hooger zoowel als lager onderwijs is een Staat, die neutraal moet blijven, tot het geven vall onderwijs onbekwaam" (De Villiers \& Coetzee, s.j.:17) en dit word kinders op die pad van die revolusie geplaas. Vir Coetzee staan die Vrywillige Beginsel in verband met die "Afrikaansche nationaliteit" en die behoud van die gereformeerde leer (De Villiers \& Coetzee, s.j.:22, 24). As die neutrale skole die onderwys "uit de handen van ouders" neem, "handelt men in strijdt met de ordonantiën Gods" (De Villiers \& Coetzee, s.j.:26). Vir Coetzee lei so 'n stap tot 'n broederskap buite Christus en sonder Gods Woord. Volgens Coetzee is die grondslag vir wetenskap die godsdiens, gewortel in die bodem van geloof en geheilig deur die Woord en Gees van Christus (De Villiers \& Coetzee, s.j:27).

\section{Du Toit neem aanstoot aan Kuyper}

Ds. Du Toit was besig om in Transvaal gevolg te gee aan sy gereformeerde oortuigings en politieke ideale. Ondat Kuyper moes help om die Republiek met regsinniges te bevolk, is sy voorspraak ook ingeroep, maar die Afrikaanse en Nederlandse bondgenote het mekaar begin verkwalik.

Die vertroueling van die president is aangewys as voorsitter van 'n immigrasiekommissie wat in 1882 tot stand kom. Daar is geskakel met Kuyper wat lid was van die emigrasiekommissie in Nederland (Schutte, 1968:45 e.v.).

Die twee het gehoop om 'n groot invloed en beheer oor die godsdienstige gesindheid van aspirant emigrante na die Transvaal uit te oefen. Dat die twee ook vas van plan was om hulle stempel op die Transvaal af te druk, Transvaal vir die sogenaamde godsdienstige reggesindes gereserveer wou 
hê, liberalisme uit wou skakel, daarvan het verder die planne wat dr A Kuyper in dié tyd gekoester het, om $\mathrm{nl}$ in belang van regsinnige Nederland 'n reis na Transvaal te maak, getuig (Van der Walt, 1944:21).

Van hulle poging het egter nie veel gekom nie (Van Winter, 1937, 1938:I 50-55).

Jorissen, wat op besoek in Nederland was, is ontslaan (Scholtz, 1975:154 e.v.) 'n stap wat Du Toit se beeld en uitgangspunte nie goed gedoen het nie. In 1883 was hy saam met pres. Kruger en genl. Smit lid van 'n deputasie na Engeland. Du Toit was egter nie tevrede met Kuyper se begeleiding nie (Van der Walt, 1944:60; Scholtz, 1975:157 e.v.; Schutte, 1986:176 e.v.). Kuyper het in London kom help om ' $n$ antwoord op te stel teen die negrofiliste wat teen die deputasie betoog het en Transvaal van slawerny beskuldig het (Van der Walt, 1944:44; Kruger, 1930:94); sy beriggewing in De Standaard het egter na die oordeel van Du Toit nie gunstig in London oorgekom nie. Om "voortaan alle misverstand te voorkomen", het Kuyper hom versoek om "mij desnoods woordelijks te willen meedeelen, wat gij gepubliceerd wenscht" (aangehaal deur Scholtz, 1975:161). Die vraag ontstaan dus of Kuyper Du Toit verkeerd verstaan het en of Du Toit eiesinnig was.

As Kuyper hom inlig oor hoe daar in Nederland vrae gevra word oor die "Jorissen-kwestie", stuur hy aan hom inligting daaroor vir publikasie in De Standaard. Oor die feit dat die Calvinisme Nederland en Transvaal aan mekaar verbind, bly Kuyper opgewonde: daarvan getuig sy Plancius-rede (Du Toit, 1886: 42). Kuyper en Du Toit het mekaar begin verkwalik oor uitlatings en beriggewing (Schutte, 1986:178). Dit is duidelik dat Kuyper nie genoee geneem het met wat Du Toit oor die VU te sê gehad het nie (Scholtz, 1975:165-166). Tuis het De Getuige tog ondersteuning van "de voorstanders der Vrije Universiteit" gevra (1884-03-15): die vordering van Christelike skole in Nederland is in detail aangegee $(D . G ., 1884-05-15$, p. 76 e.v.; 1884-06-15, 1884-08-15, p. 131 e.v.; 1884-10-15, p. 157) en daar is telkens uit Kuyper se werke aangehaal (bv. D.G., 1884-08-15, p. 124, 125).

\section{Die afskeiding wat Kuyper oorweeg, laat Du Toit nadink}

Kuyper bly egter 'n wegwyser: in Nederland het Du Toit die stryd in die Hervornnde Kerk wat op die Doleansie sou uitloop van naderby leer ken. Hy het kennis geneem van Kuyper wat Luther en Calvyn laat sê:

De Kerk reformeerd hoe dan ook. Kan het zonder breuke, dan zonder breuke, maar moet het. dan desnoods met breuke. Gods Woord eisch doortasendheid en beslistheid van raad! (D.G., 1885-11-15, p. 172).

"En is de tijd niet nabij of reeds gekomen," so vra hy self, "waarop ook de Protestantsche kerken, ook de Ned Geref Kerk niet meer te redden is dan over 
breuke met het bestaande kerkverband?" (D.G., 1885-11-15, p. 172). In sy werkie van 1885, Nehemia als Volkshervormer ook ons ten Voorbeeld praat hy van homself. Hierdie publikasie het as artikels begin (D.G., 1884-09-15, p. 133 e.v.). Nehemia is "de vrome patriot," "edele volkshervormer" in wie "patriotisme en godsvrucht, vrijheidszin en geloofsmoed, vaderlandsliefde en godsdiensijver zoo liefelijk en leerrijk vereenigd zijn" (Du Toit, 1885:1, 2).

As die Doleansie in 1886 plaasvind, vra De Villiers die sinode om simpatie te betuig "met die afgezette Broeders in Holland" (Acta Synodi, 1886:153a, Bp 95). Hy het egter die beskrywingspunt teruggetrek (Acta Synodi, 1886:128). Die Gemeente van Noorder-Paarl, waar ds. A.A. Louw toe predikant was, het wel in 1887 'n brief van simpatie aan die Dolerendes gestuur (D.G., 1887-02-14, p. 171).

In 1889 skrywe De Villiers aan sy vriend ds. (later prof.) A. Moorrees oor 'n moontlike beroep na die GK.

Het zou mij ook niet besonder leed doen, om de Ned Geref Kerk, zoals zij thans in een toestand van innovalie en transilie verkeerd, te verlaten (aangehaal deur De Kock, 1981:322; Moorrees-versameling).

Die GK was 'n vrye kerk wat erns gemaak met vrye skole waarin die kerk meespreek (vgl. Spoelstra, 1963:271-274; Jooste, s.j.:306-308; Van der Vyver, 1958:421-426). Du Toit het oor afskeiding of kruiskerke begin praat (Scholtz, 1975:319 322).

\section{Die ontdekking van goud in Transvaal - Du Toit se siening}

Du Toit het die ontdekking van goud in Transvaal gesien as ' $n$ bestiering van God. Hy handhaaf hierdie sienswyse ten spyte van die teenstand teen sy persoon in Transvaal en sy standpunt in die Kaapkolonie. Die ontdekking van goud in 1886 het hom as profeet en ondernemer aangespreek. Die vraag wat na vore kom, is egter watter koers S.J. du Toit persoonlik besig was on in te slaan en wat hy in die ZAR en in die Kaapkolonie beoog het.

Die gawe van goud aan die ZAR het hy gesien as ' $n$ moontlikheid om sy ideaal van 'n verenigde Suid-Afrika te bereik. Ook het hy dit gesien as die antwoord van die Here op sy belofte om heeltyds sy aandag te wy aan die vertaling van die Bybel in Afrikaans (Scholtz, 1975:184 e.v.; Du Toit, 1889:26 e.v.; D.G., 188611-15). In 1885 het hy die Here juis belowe om die vertaling op versoek van die GRA te onderneem as Hy binne 'n sekere tyd aan hom 10000 pond skenk! (Du Toit het selfs sy hand in die mynbedryf gewaag.)

Ondertussen was hy nie as profeet in aansien nie - ook nie as staatsamptenaar in Transvaal nie; hy moes telkens laster verduur (Scholtz, 1975:176-177). Met De 
Volkstem het hy nooit reggekom nie (Scholtz, 1975:153 e.v., 180) en sy verhouding met die kerke in die ZAR was ook nie bevredigend nie (Scholtz, 1975: 179183). Hy het hom al meer met die politiek ingelaat en eiesinnig opgetree. Toe pres. Kruger aan sy praktiese staatsmanskap begin twyfel, toe word hy sakeman!

Sy onderwysbeleid in die ZAR het teenstand ondervind. Daarmee saam het die Christelik-nasionale uitgangspunte van Kruger, wat so sterk ingestel was op Holland, reaksie uitgelok (Davenport, 1966:48-49, 320-331; Gordon, 1970). In die Kaapkolonie was sy onderwysbeleid nog steeds nie aanvaarbaar nie. In 1886 het die Wetgewende Vergadering 'n voorstel vir vrye skole in die Kaapkolonie afgestem (1885-07-09), en weer in 1889 (De Zuid-Afrikaan, 1889-07-20; Du Toit, s.j. :47). Du Toit was ontstel, veral ondat die provinsiale bestuur van die Afrikanerbond hom in 1886 teen vrye skole uitgespreek het (De Zuid-Afrikaan, 1886-04-03). In aansluiting by die meerderheid in die NGK het Onse Jan vir aanpassings van die onderwyswet beding. In Mei 1886 het die Wetgewende Vergadering ' $n$ verdere toegewing gemaak.

Het Schoolkomité zal mogen zorg dragen voor het onderwijs der leerlingen in de godsdienst gedurende de gewone schooluren (I.A.P., 1886-05-07).

Die vrye skool was nie meer nodig nie, altans so is gesè (De Zurd-Afrikaan, 1886-05-04; J.D. du Toit, 1917:44-47; Bingle, 1954:101, 109). Oom Lokomotief het die toegewing afgemaak as " 'n skyn verandering, wat eenvoudige, vrome goedgelowige gristene di oge sal verblinde" (I).A.P., 1886-05-07). De Villiers was dit met hom eens (I).A.P., 1886-08-20)

In die Sinode van 1886 het ds. I. H. Hofineyr van Somerset-Oos De Villiers en Du Toit verwyt dat hulle te veel waarde heg aan die voorbeeld van Holland en Abraham Kuyper en gestel dat staatskole nie godsdiensloos is nie. "Hief men de Staatsonderstand op, dan zouden de Scholen niet gaan" (De Zuid-Afrikaan, 188610-30). Die sinode het besluit "dat met het oog op verbeterde schoolregulaties, onze Kerk zich meer beijveren moet ondersteuning van Regeringswege te bekomen, vooral ook voor de Buitescholen" (Acta Synodi, 1886:98-100).

In 1888 het ds. Du Toit bedank as Superintendent van Onderwys ondat bepaal is dat 'n amptenaar nie direkteur kan wees van 'n mymmaatskappy nie. Hy was as't ware deur sy ondernemingsgees in beslag, en deur sy ideale op sleeptou geneem.

In 1889 besoek hy Europa nog 'n keer, vergesel deur sy broer, ds. C.W. du Toit. Hierdie keer laat Kuyper in De Standaard hoor dat hy sy ou vriende vermy (Ploeger, 1952:61). Kuyper se advies is nie gesoek nie, ook nie vir 'n beplande Universiteit in die ZAR nie (Ploeger, 1952:58, 62).

Terwyl hy oorsee was, het sy ondememings in Transvaal bankrot gespeel (Van Winter 1937, 1938:1I 18). Sy weg het eensaam geword 


\section{Du Toit se ywer vir Afrikaans word nie deur De Villiers gedeel nie}

Ds. De Villiers het koers gehou en hom gehou aan die NGK, maar in De Getuige (1890-02-15) was hy diep bekommerd omdat "onze Nederduitsch Gereformeerde Kerk in een kritieken toestand" is (D.G., 1890-02-15, p. 22-25). In hierdie kritiek vereenselwig hy hom met S.J. du Toit (Oberholster, 1956:218-224). Hy sou egter kies vir Nederlands eerder as vir Afrikaans.

Dat die openbare skool 'onkerklik' (undenominational) heet, is vir die kerk 'n oneer. Dit ontstel hom dat Engels daarin nog steeds voorrang geniet. Volgens De Villiers is die skole die ondergang van die NGK. Hy kritiseer Andrew Murray openlik deur te sê dat ten spyte van Murray se groot werk in Wellington bly die vraag "Wordt liefde en achting voor de kerk aldaar aangekweekt?" Op die Hugenote "School" is Engels selfs die taal van die godsdiens, daar is ' $n$ Engelse Sondagskool en in die "Opleidings School" is alles Engels. Hy stel dit dat die aanstaande sendelinge van die "Nederduitsch Geref Kerk, worden opgeleid door een man, die geen Hollandsch verstaat en zelden of ooit zijne voeten zet over den drumpel van het Ned Geref Kerkgebouw te Wellington" (D.G., 1890-02-01, p. 24-25). Sy artikel het in De Heraut weerklank gevind (1890-03-30)

Die vraag kan gevra word of hierdie uitspraak van Du Toit die rede was vir A Murray se beskrywingspunt by die Sinode van 1890 wat vra "naar meerdere voorziening in het Hollands onderricht op de publieke school"? (Acta Synodi, 1890:17; kyk Du Plessis, 1920:418 e.v.). Al meer mense het aangedring op die handhawing van Nederlands. Tydens die sitting is 'n taalkongres in Kaapstad gehou op Vrydag 31 Oktober en Saterdag 1 November. Prof. P.J.G. de Vos is as voorsitter gekies en De Villiers as visevoorsitter. By die geleentheid is die "ZuidAfrikaansche Taalbond" gestig. Daarmee het De Villiers standpunt ingeneem teenoor Du Toit met sy ywer vir Afrikaans.

In 1891 het hy lid van die Wetgewende Raad geword. Rhodes het die vorige jaar Eerste Minister geword met die ondersteuning van die Afrikanerbond (Davenport, 1966:133; Hofmeyr \& Reitz, 1913:429). Opnuut is ingetree vir onderwys op die platteland en die erkenning van Nederlands in die howe en skole (De Kock, 1981:344 e.v.).

\section{Du Toit vervreem hom ook van sy Afrikaanse vriende}

Nadat S.J. du Toit terug in die Kaap was met sy rug gekeer op Kuyper, het hy homself ook vervreem van sy vriende in Transvaal en die Kaapkolonie. Kerklik was sy aanhang egter nog sodanig dat dit 'n doleansie aan die gang gesit het. Met 'n 'linksomkeer' het hy as Kapenaar die Engelse bestel gaan voorstaan terwyl hy 
dit in die geskiedsbeeld wat hy aanvanklik help verwoord het, aangekla het (Scholtz, 1975:192 e.v.); gevolglik het baie ander landseuns wat hy voorheen beskuldig het, daarmee ontevrede geraak.

Hy het hom weer in die Paarl gevestig en is in die redaksie van Di Patriot opgeneem, maar sy profetiese omgang met die hede en verlede het hom polities met ander insigte laat werk. In De Express (1891-04-26) word gevra of hy leier van die Afrikanerbond wou word. Du Toit het Rhodes as Eerste minister aanvaar en een van sy "most-devoted adherents" geword (Williams, 1938:67). Sy ideaal van 'n verenigde Suid-Afrika het hy gaan verbind aan Britse kusbeskerming (D.A.P. 1891-01-08). Die vraag ontstaan dus waarom hy sy negatiewe houding teenoor Engeland prysgegee het vir 'n positiewe waardering (Blok, s.j.:27; Nienaber, 1940:7; Scholtz, 1975:192 e.v.). 'n Moontlike antwoord is dat sy negatiewe benadering hom uitgelewer het aan frustasie; uiteindelik was hy keelvol vir "die ellendige knoeiery van die Hollander kliik op Pretoria" (D.A.P. 1891-12-17) en het hy verkies om "honderd maal liewer ... onder de Engelse Regering te lewe as onder so 'n Republiek" (D.A.P. 1894-08-28).

Oor die Adendorff-Trek (1889-1891) het hy met sy ouer broer, Oom Lokomotief, verskil en kwaaivriende geword Vanaf April 1891 het Du Toit alleen opgetree as redakteur vall Di Patriot (ID.A.P., 1891-06-11) en daarmee het hy ook C.P. Hoogenhout van hom vervreem. Sodoende het 'n skeuring in die geledere van die GRA ontstaan (Scholtz, 1975:199 e.v.). Sy ondersteuning van Rhodes ten opsigte van die Adendorff-Trek het hom ook vervreem van De Villiers (Davenport, 1966:136). In 1892 het Oom Lokomotief in Ladybrand onderwyser geword (Blok, s.j.:94), en in 1894 De Express opgerig (1894-08-06) waarin hy dadelik die rigting teeegegaan het waarin sy broer, ds. S.J. du Toit, opgegaan het (De Express, 1894-11-09). In die Afrikanerbond is hy al minder aanvaar (Scholtz, 1975:206 e.v.).

Kerklik-teologies het hy egter aansien bly geniet - selfs in 'n meerdere mate. Te midde van "smaad en miskenning" het De (jetuige sy lesers vermeerder. Vanaf 1892 het dit twee maal in 'n maand verskyn (D.G., 1892-01-01, $\left.\mathrm{p}_{\llcorner} 1\right)$.

Die vraag ontstaan of die die kerkvereniging van 1892 wat Kuyper gelei het, hom twee keer laat dink het aangesien die fout wat hy met die NGK gevind het, tog uitgeloop het op Gereformeerde Kerke onder die Kruis (vgl. Oberholster, 1956: 232-246; Badenhorst, 1976:15-20)

Dit is ironies dat al meer Engelsgesmdes wat Du Toit eers verkwalik het, die Engelse bewind negatief belewe het. Enkele maande na die Jameson-inval op 29 Desember 1895 het 'n groot aantal predikante, onder andere proff. N.J. Hofmeyr, J.I. Marais en P.J.G de Vos, dr. A Murray, di. A Moorrees, J.H. Neethling, A.I. Steytler by W.P. de Villiers aangesluit en die Hoe Kommissaris, sir Hercules 
Robinson, laat verstaan het dat hulle die daad en Rhodes se aandeel daarin ten sterkste afkeur. Suid-Afrika moes toegelaat word om vir homself rigting te vind (Ons Land, 1896-05-16). Die Jameson-inval was "the first shot fired in the Boer war" (Molteno, 1923:68; kyk verder Hofmeyr, 1896; Van der Poel, 1951; Hale, 1930).

Engelse middagdienste, wat deur 144 lidmate in Julie 1892 in die Gemeente van Wellington aangevra het, is in 1896 gestaak weens gebrek aan belangstelling (NG Kerkraad van Wellington, Notule, 1840-1907:326, 332, 334-336, 338, 380). Prof. De Vos het gemeen dit is "een laffe naäprij en mode als onze predikanten Engelsche diensten houden" indien dit nie 'n werklike behoefte is nie (Ons Land, 1897-03-11).

\section{Du Toit as 'n kulturele profeet bewys}

Ten spyte van sy politiek was die Paarliet S.J. du Toit tog 'n kulturele profeet. Die Afrikaner se taal was nie meer Hollands nie, maar Afrikaans. Polities het hy egter nie sy insig waargemaak nie.

Die Afrikaanse Taalkongres op 15-16 Januarie 1896 het 'n ongekende toeloop gehad: die twintigjarige bestaan van Di Patriot is gevier en meer as 100 kongresgangers van oor die hele land was daar. Uit Burgersdorp het die twee professore, Jan Lion-Cachet (1838-1912) (kyk SABW I: 151-153) en S. Postma (1865-1904) (kyk Van der Vyver, 1969:55 e.v.) met twee studente van die Teologiese Skool van die GK gekom. Ook ds. M. Postma van Middelburg was daar. Prof. Postma het die naam Ons Klyntjie voorgestel vir die letterkundige tydskrif waarop besluit is. Hierdie besluit het inderdaad ' $n$ waardering vir die moedertaal gekweek (Von Wielligh, 1922:86 e.v.; Van Niekerk, 1920:31 e.v.).

Gedurende dieselfde jaar (1896) het ds. S.J. du Toit sy seun J.D. du Toit (die later bekende Totius) aan hierdie skool eerder as aan die Teologiese Seminarium van Stellenbosch laat inskrywe (Van der Vyver, 1969:63 e.v.)

Die Tweede Taalkongres van Januarie 1897 het aangedring op die erkenning van Afrikaans as amptelike taal (D.A.P., 1897-01-28).

Die vraag kan dus gestel word waarom Du Toit Het Daghlad, die eerste koerant wat daagliks verskyn het, in Nederlands uitgegee het, terwyl hy Afrikaans wou bevorder? Was dit om politieke redes en het Rhodes dit gefinansier? (Hofmeyr \& Reitz, 1913:564; De Waal, 1932:42; Bosman \& Dreyer, s.j.: 15; Scholtz, 1975:211). Die Daghlad het vir slegs twee jaar lesers gehad (Het Daghlad, 1898-09-30). 
In 1898 moes ds. Du Toit 'n ander politieke tuiste vind en het hy "De Koloniale Unie" gestig (D.A.P., 1898-04-28). Die Program van Beginsels het hemelsbreed verskil van dié wat hy van Kuyper oorgeneem en vir die Afrikanerbond in 1879 opgestel het. Die Unie het "Engelands oppergezag in Zuid-Afrika" aanvaar, onderneem om goeie verhoudinge tussen Afrikaners en Engelse te bevorder; vir "een inwendig Vereenigde Zuid-Afrika" geywer en Nederlands saam met Engels as amptelike tale erken. Die nuwe party was nie lewensvatbaar nie en Du Toit met sy groepie persoonlike aanhangers is verontagsaam (Davenport, 1966:176).

\section{Du Toit handhaaf homself as 'die eensame Ismael'}

Toe die Tweede Vryheidsoorlog op 11 Oktober 1899 uitbreek, het Kuyper en baie Nederlanders hul aan die kant van die Boere geskaar (Schutte, 1986:73 e.v.). W.P. de Villiers het hom met die Noordelike republieke vereenselwig en was sterk afkeurend teenoor die Engelse imperalisme (De Kock, 1981:399 e.v.). S.J. du Toit het vir Engeland kant gekies. Sy seun, Jacob Daniel, wat in Junie afstudeer het, het egter as predikant by die Transvaalse kommando's aangesluit! Toe hy ' $n$ jaar later aan die VU verder gaan studeer, het hy aan Kuyper erken dat hy polities van sy vader verskil (D'Assonville, 1971).

In 1904 het die firma D.F. du Toit en Kie bankrot gespeel en in Oktober 1904 het Di Patriot en De Getuige opgehou om te verskyn. "Ons werk van een leeftijd," het Du Toit laat hoor, "wordt hienneê nu afgebroken" (D.A.P., 1904-10-23; D.G., Okt. 1904, p. 193).

In 1905 het Du Toit begin met die tydskrif Stemmen des Tijds met die tiperende opskrif "Gij moet wederom profeteren - Openb. 10:11". Hierdie tydskrif was hoofsaaklik godsdienstig van aard.

In 1905 is die Gedenkskool in Dal Josafat gesluit en na 1906 het Ons Klyntjie nie weer die lig gesien nie. Du Toit het begin met Ons Taal maar in 1909 het dit ook opgehou.

\section{Samevatting}

Ds. S.J. du Toit was ' $n$ profeet wat kontekstueel verstaan moet word. Ds. G.W.A. van der Lingen het hom geleer om gereformeerd profeties met sy eie tyd en die verlede om te gaan. Soos sy leenmeester het hy op gereformeerde skole onder toesig van die kerkraad aangedring, daarom het die Neo-Calvinis, Abraham Kuyper, sy gids geword. As teoloog sou Kuyper die Afrikaanse profeet bly beinvloed, maar nie polities bevredig nie. Die profeet van Paarl het ' $n$ geskiedsbeeld verwoord in die taal wat die Afrikaners vir hulleself aangeleer het. In hierdie taal sou hulle hulleself ontdek. Die Afrikaanse profeet se ervaring in die 
Transvaal, wat veroorsaak is deur Nederlanders, sou hom egter vervreem van Kuyper en sy vriende en homself in diskrediet bring. Dat hy aanhang by lidmate van die NGK geniet het, word bewys deur die feit van die totstandkoming van Gereformeerde Kerke onder die Kruis. Daarin staan ook die naam van Kuyper aangeteken.

\section{Bibliografies}

AALDERS, W. 1984. "Luther-Kohlbrugge-Kuyper", De tijdgeest weerstaan. Amsterdam. ANON. 1873. Herinnering aan het leven en de werksaamheden van den Wel-Eerw zeer Gel Heer Goth Wilh Ant van der Lingen Paarl.

BADENHORST, L.H. 1955. Die aandeel van die kerk in die opvoeding, spesiaal in die Kaapprovinsie. Amsterdam.

BADENHORST, M.J. 1976. Die Kruiskerk en die Strydenburgse kerkkwessie met di S.J du Toit en Andrew Murray in twee kampe. Stellenbosch

BEIJER, J. s.j. Joemaal gehouden van Port Elizabeth (Algoabaai) naar Reddersburg (Oranje Vrijstaat) in het jaar 1861, alsmede de Redenen der Afscheiding van de NederdGereformeerde Kerk.

BINGLE, P.W. 1954. Die Gereformeerde Kerk en die Onderwys in Suid-Afrika 1859-1959 Ongepubliseerde M. Ed.-verhandeling, PU vir CHO

BLOK, T. s j Die Adendorff-Trek Bloemfontein

BOSMAN, F.C.L. \& Dreyer, A s.j Hollandse joernalistiek in Suid-Afrika gedurende die 19 de eeu en lewensketse van Hollandse Joernaliste in Kaapland. Sp

BROWN, W 1987. Dominee Johannes Henoch Neethling Hzn 1851 - 1904, 'n yweraar vir godsvrug Ongepubliseerde D.Th -proefskrif. US

CACHET, F. L. 1875 Vijftien jaar in Zuid-Afrika, brieven aan een vriend Leeuwarden.

CILLIERS, DH 1953. Die stryd van die Afrikaanssprekende in Kaapland om sy eie skool Kaapstad

COERTZEN, P 1988. Die Hugenote van Suid-Afrika, 1688-1988 Kaapstad

COETZEE, J. Chr. 1946. Ds. S.J. du Toit en die onderwys. Johannesburg

COOPER, A.A. 1986. The Freemasons of South Africa Cape Town.

D'ASSONVILLE, V.E. 1971. Dr. J.D du Toit (Totius) se opleiding en vorming as predikant. PU vir CHO. (Th.M.-verhandeling.)

DAVENPORT, T R H 1966. The Afrikaner Bond, the History of a South African Political Party, 1880-1911 Cape Town.

DE KOCK, M.G.W 1981 Ds. Willem Petrus de Villiers, Woordbedienaar in 'n voorpossamelewing Ongepubliseerde D.Th -proefskrif, US

DE VILLIERS, A.J D. 1936. Die Hollandse Taalbeweging in Suid-Afrika. Stellenbosch.

DE VILLIERS, W P. \& Coetzee, M.P. sj. De bezwaren tegen de toepassing van het Vrijwillig Beginsel op Schoolen bewogen en te Licht Bevonden Paarl

DE WAAL, J H H 1932. My herinnerings aan ons taalstryd Kaapstad

DOUMA, J. $1976^{3}$ Algemene genade, uiteensetting en beoordeling van de opvattingen van $A$ Kuyper, K Schilder en Joh Calvijn over algemene genade Goes

$5 \quad$ Volgens In die Skriflig se redaksionele beleid moct die uitgewers van publikasies in dic bibliografie vermeld word Op versoek van die outeur word hierdie spesifieke artikel geplaas sonder dat die uitgewers vermeld word 
DREYER, J. 1943-44. Die neo-calvinistiese leer van die wedergeboone. Hervormde Teologiese Studies, 1:21-31

DU PLESSIS, J. 1920. Het leven van Andrew Murray Kaapstad

DU TOIT, J.D. 1917. Ds. S.J. du Toit in weg en werk, 'n periode van Afrikaanse oplewing Paarl.

DU TOIT, P. S. 1946. Onderwys in Kaapland, 1652-1939 Pretoria.

DU TOIT, S.J 1877 Repliek op alle Recensien van het werkje "De Christelijke School in hare verhouding tot Kerk en Staat". Kaapstad.

DU TOIT, S J. 1878. De Christelijke School, in haar verhouding tot Kerk en Staat. Paarl.

DU TOIT, S.J. 1880. Een sprekend portret van die Laaste Dagen. Paarl.

DU TOIT, S.J. 1881. Op reis door Duitschland ... Paarl.

DU TOIT, S.J. 1885. Nehemia als Volkshervormer ook ons ten voorbeeld. Paarl

DU TOIT, S J 1886. Alweer op reis, die slag as lid van die Transvaalse Deputasie, in 18831884. Paarl.

DU TOIT, S.J. 1889. Die Bybel in Afrikaans, drie proewe, met historiese ontleding. Paarl.

DU TOIT, S J. 1895 De Predestinatie volgens Bijbelleer en kerkleer, op nieuw in't licht gesteld Paarl.

DU TOIT, S.J. 1895. Di geskidenis van ons land, in di taal van ons volk Paarl.

DU TOIT, S.J. s.j. De Vrij School voor't Kaapsche Parlement onrechtvaardig veroordeeld Paarl

ELPIS, Algemeen Tijdsschrift voor Zuid-Afrika $1857-1861$

ELPIS, Tijdsschrift voor Kerk en Teologie $1873-1879$.

ENGELBRECHT, S.P. 1946 Dr A Kuyper en John Milton Hervormde Teologiese Studies, $3: 46$

GEDENKBOEK Dr. A Kuyper 1937. Kampen

GEDENKBOEK van de viering van het 50-jarig bestaan der Vrije Universiteit te Amsterdam op 20-22 October 1930 1931. Kampen.

GEELHOED, J. 1975 Kuyper blies verzamelen. Zijn strijd tegen de geest van de 19de eeuw Goes.

GORDON, C.T. 1970. The Growth of Boer Opposition to Kruger (1890-1895) Cape Town.

GREYLING, E. 1946 Godsdiensonderwys - in die skool. Bloemfontein

GROOT, $\mathrm{K}$ 1956. Kohlbrugge en Kuyper in hun wederzijds contact Baarn

GROSHEIDE, D 1939 Lijst van geschriften betreffende dr. A. Kuyper Amt/-Revolutionaire Staatkunde, 13

HAITJEMA, Th L. 1931. Abraham Kuyper und die Theologie des hollandischen Neocalvinismus Zwischen der Zeiten, 9de Jaargang

HALE, HM 1930. The Jameson Raid London

HANEKOM, T.N. 1956. Ord 7-1843, kort oorsig oor die voorgeskiedenis en-ontstaan van die Kerk-ordonnansie Geref Vaandel, Des

HANEKOM, T N. 1951. Die Liberale rigting in SA. Stellenbosch

HEXHAM, I 1981. The Irony of Apartheid The Struggle for National Independence of Afrikaner Calvinism against British Imperialism New York-Toronto.

HOFMEYR, J.H \& Reitz, ZW. 1913. Het leven van Jan Hendrik Hofmeyr (Onze Jan) Kaapstad

HOFMEYR, N J 1896 De Afrikaner Boer en de Jameson-inval Amsterdam

JEPPE, F \& Kotze, J.G red 1887. De Locale Wetten der Zuid-Afrikaansche Republiek, 1849-1885 Pretoria.

JONKER, W D. 1989 Die pluriformiteit van Abraham Kuyper In die Skriflig, 91:12-23, Sept 
JOOSTE, J.P. s.j. Die geskiedenis van die Gereformeerde Kerk in Suid-Afrika, 1859-1959. $\mathrm{Sp}$.

JORISSEN, E.J.P. 1897. Transvaalsche herinneringen 1876-1896. Amsterdam-Pretoria.

KASTEEL, P. 1938. Abraham Kuyper. Kampen.

KESTELL, J.D. 1911. Het leven van professor N.J. Hofmeyr Kaapstad.

KITSHOFF, M.C. 1972. Gottlieb Wilhelm Antony van der Lingen, Kaapse predikant uit die negentiende eeu. Groningen.

KLUIT, ME. 1936. (uitgebr. uitg.) Het Réveil in Nederland 1815-1854. Amsterdam.

KOLFHAUS, W. 19252. Dr. Abraham Kuyper. Elberfeld

KRUGER, D.W. 1930. Die Republiek Stellaland Potchefstroom.

KRUGER, L.S. 1975. Die rol van dr. E.J.P. Jorissen in die geskiedenis van die ZAR. Ongepubliseerde verhandeling, UOVS.

KUYPER, A. 1879. Ons Program. Amsterdam.

LANGEDIJK, D. 1931. Bibliografie van den schoolstrijd 1795-1920. 's-Gravenhage.

LANGEDIJK, D. 1953. De geschiedenis van het Protestants-Christelijk onderwijs. Delft

LANGMAN, H.J. 1950. Kuyper en de volkskerk, een dogmatisch-ecclesiologische studie. Kampen

LAUTS, U.G 1847. De Kaapsche landverhuizers of Neerlandsafstammelingen in ZuidAfrika Leiden.

MAEDER, G.A. red. 1916 Ons Kerk Album. Kaapstad.

MALHERBE, E G 1925. Education in South Africa (1652-1922) Kaapstad

McCARTER, J. 1875. Geschiedenis der Nederduitsche Gereformeerde Kerk in Zuid-Afrika Amsterdam.

MOLTENO, J T 1923 The Dominion of Afrikanerdom London

MOUTON, J.F. 1980. Die Ned Geref. Kerk en die Eerste Vryheidsoorlog 1872-1884 Ongepubliseerde M.Th -verhandeling US

MULLER, C.F.J. red 1937. 500 jaar Suid-Afrikaanse geskiedenis Kaapstad

NIENABER, P.J. red. 1974. Notules van die Genootskap van Regte Afrikaners, 1875-1878. Kaapstad.

NIENABER, P.J 1968 Dr. Arnoldus Pannevis, vader van die Afrikaanse taal Kaapstad

NIENABER P.J 1940 Ds. JD du Toit die eensame Ismael, 'n beskouing oor sy letterkundige werk Pretoria.

NOORDER-PAARL KERKRAAD 1876. Ontstaan van de Gemeente Noorder-Paarl. Paarl

OBERHOLSTER, J.A.S. 1956 Die Gereformeerde Kerke onder die Kruis in Suid-Afrika Hul ontstaan en ontwikkeling Kaapstad-Pretoria.

PLOEGER, J. 1940 Ulrich Gerhard Lauts (1787-1865), skakel tussen Nederland en die Voortrekkers Historiese Studies, I, 4 (1940), 1-27; II, 1, 2 (1940), 1-70.

PLOEGER, J. 1945-46. Dr. E.J.P Jorissen Tydskrif vir Wetenskap en Kums, V:39 e v. (1945), VI:32 e.v. (1946)

PLOEGER, J 1952 Onderwys en onderwysbeleid in die Suid-Afrikaanse Republiek onder S J du Toit en dr N Mansvelt (1881-1900) Argief Jaarboek, 1

PONT, A.D. 1987. Die betekenis van Abraham Kuyper (1837-1920) vir Suid-Afrika op kerkhistoriese en kerkregtelike gebied Hervormde Teologiese Studies, 43(3):506-521

POTGIETER, M du T 1961 Die Nederduitse Gereformeerde Kerk en die onderwys van blankes in Kaapland sedert die Eerste Sinode (1824). Ongepubliseerde D Ed -proefskrif, US

PRAAMSMA, L 1945 Abraham Kuyper als kerkhistoricus Kampen

PUCHINGER, G \& SCHEPS, N. 1971 Gesprek over de onbekende Kuyper Kampen 
PUCHINGER, G. 1987. Kuyper-herdenking 1987 (Die religieuze Kuyper) Vijf opstellen en lezingen ter gelegenheid van de honderdvijftigste geboortedag van Abraham Kuyper, 29 Okt. 1987. Kampen.

RAS, J.L. 1979. Die lewe en werk van ds. MP A. Coetzee (Jr) 1851-1901. Ongepubliseerde Th.M.-verhandeling, $\mathrm{PU}$ vir $\mathrm{CHO}$.

RIDDERBOS, S.J. 1947. De theologische cultuurbeschouwing van Abraham Kuyper. Kampen

ROELINK, J. 1956. Vijfenzeventig jaar Vrije Universiteit 1880/1955. Kampen.

RULLMANN, J.C. 1930. 1880 - 20 October 1930, de Vrije Universiteit haar ontstaan en haar bestaan. Amsterdam

RULLMANN, J.C. 1928 Abraham Kuyper, een levensschets. Kampen.

RULLMANN, J.C. 1923-40. Kuyper-bibliografie 3 dele 's-Gravenhage

SABW

$k y k$

SUID-AFRIKAANSE BIOGRAFIESE WOORDEBOEK, 5 dele RGN

SCHOLTZ, D.A. 1975. Ds. S.J. du Toit as kerkman en kultuurleier Ongepubliseerde Th.D. proefskrif, US.

SCHOLTZ, J du P. 1964. Die Afrikaner en sy taal 1806-1875. Kaapstad.

SCHUTTE, D J. 1986. Nederland en de Afrikaners, adhesie en aversie Franeker.

SCHUTTE、 G.J. 1968 De Hollanders in Krugers Republiek 1884-1899. Pretoria

SMIT, A.P 1945 Gedenkboek van die Ned Geref. Kerk Beaufort-Wes Kaapstad

SMIT, C.J. 1989. Abraham Kuyper as kerkregkundige In die Skriflig, 23(91):24-44

SMIT, J.H. 1989. Abraham Kuyper en volksideologie onder die Afrikaners In die Skriflig, 23(91):45-55

SPOELSTRA, B. 1963. Die Doppers in Suid-Afrika, 1760-1899. Kaapstad

STELLINGWERFF, J 1987. Abraham Kuyper en de Vrije Universiteit Kampen

VAN DER LINDE, S 1958. Kuyper en Calvijn Wapemveld, 8(1) 8-10

VAN DER POEL, J. 1951. The Jameson Raid Kaapstad

VAN DER VYVER, G.C.P. 1958 Professor Dirk Postma Potchefstroom

VAN DER VYVER, G C P 1969 My erfenis is vir my mooi Potchefstroom

VAN DER WALT, A.J.H red s j. Geskiedenis van Suid-Afrika Kaapstad

VAN DER WALT, C. 1944 S J du Toit in die diens van die Suid-Afrikaanse Republiek, 1882-1890 Ongepubliseerde M A -verhandeling, UP

VAN DER WATT, PB 1973. Die Loedolff-saak en die Nederduitse Gereformeerde Kerk 1862-1962 Kaapstad

VAN JAARSVELD, F A. 1954 Tyd en geskiedsbeeld - 'n metodologies-kritiese studie oor die werk van dr. W J Leyds. Tydskrif vir Wetenskap en Kuns:97-1907.

VAN JAARSVELD, F.A. 1959. Die Afrikaner en sy geskiedenis Kaapstad-

VAN KOPPEN A.J 1992. De Geuzen van de negentiende eeuw Abraham Kuyper en ZuidAfrika Maarsen

VAN LEEUWEN, P.A 1946 Het kerkbegrip in de theologie van Abraham Kuyper. Franeker.

VAN LOON, J C A 1942 Het Algemeen Reglement van 1816 Wageningen

VAN NIEKERK, L. 1920 De eerste Afrikaanse Taalbeweging en letterkundige voortbrengselen Kaapstad

VAN ROOYEN, J.H.P. 1964 Kerk en staat - 'n vergelyking tussen Kuyper en Van Ruler Groningen

VAN RULER A A s j. Kuyper's idee eener Christelijke cultuur. Nijkerk 
VAN WINTER, P.J. 1937, 1938. Onder Krugers Hollanders, geschiedenis van de Nederlandsche Zuid-Afrikaansche Spoorweg-Maatschappy. 2 dele Amsterdam.

VANDENBERG, F. 1960. Abraham Kuyper, a Biography. Grand Rapids.

VELEMA, W.H. 1957. De leer van de Heilige Geest bij Abraham Kuyper. 's-Gravenhage

VELEMA, W.H. 1989. Kuyper as theoloog - een persoonlijke evaluatie na dertig jaar In die Skriflig, 23(91):56-73.

VENTER, E L.J. 1929. Die verband tussen kerk en skool in Suid-Afrika. Amsterdam.

VIVIER, W G H. \& S. 1975. Hart van die Groot Karoo Beaufort-Wes.

VOERMAN, J. 1954. Het conflict Kuyper-Heemskerk. Utrecht.

VOGEL, L 1937. Die politische Ideen Abraham Kuypers und seine Entwicklung als Staatsmann. Wurzburg.

VOLGER, W. 1946. De leer der Nederlandsche Hervormde Kerk, 1. Franeker

VON WIELLIGH, G.R. 1922. Eerste skrywers of laaste stem en naklank uit die Genootskap van Regte Afrikaners. Pretoria.

WILLIAMS, B 1938. Cecil Rhodes London

WINCKEL, W.F.A 1919. Leven en arbeid van dr A Kuyper. Amsterdam

WYPKEMA, A 1939. De invloed van Nederland op ontstaan en ontwikkeling van de staatsinstellingen der ZA Republiek tot 1881. Pretoria 